\title{
Satyryczne funkcje rekwizytów magicznych
}

Danuta Kowalewska 
nAP7S Seria XIV 2008

\section{Danuta Kowalewska}

\section{Satyryczne funkcje rekwizytów magicznych}

\section{Wstęp}

$\mathrm{T}$

emat tego artykułu wymaga na wstępie poczynienia kilku ustaleń terminologicznych. Wydaje się to tym bardziej pożądane, że dotąd nie doczekaliśmy się jednej powszechnie akceptowanej definicji magii, a zarówno ona, jak i jej derywaty posiadają bardzo bogate uposażenie semantyczne. Zasadniczo określa się w ten sposób wiedzę i umiejętność posługiwania się wolą w taki sposób, by uruchomione nią nadnaturalne siły powodowały sprawdzalne materialne zdarzenia ${ }^{1}$. W tradycji przedromantycznej, do której przede wszystkim odwołuje się niniejszy tekst, magia obejmowała wiedzę tajemną, ludowe zabobony, sztuczki i triki iluzjonistów oraz bardziej odległe znaczeniowo wróżbiarstwo².

W potocznym rozumieniu magiczne jest wszystko, co tajemnicze, niezrozumiałe, co nie mieści się w granicach prawdopodobieństwa, nie da się racjonalnie wyjaśnić i posiada nadzwyczajny urok w oczach obserwatora. Mówiąc o magicznym wpływie czegoś na coś, dajemy do zrozumienia, że nie znamy zasady jego działania, ale nie negujemy samego wpływu ${ }^{3}$. Magiczność tak ujmowana łączy się tu z pozycją obserwatora: to jemu, a nie działającemu podmiotowi, jakieś zachowanie wydaje się niezrozumiałe. Rekwizy-

1 Zob. R. Bugaj, Nauki tajemne w Polsce w dobie odrodzenia, Wrocław 1976, s. 8.

2 Zob. J. Collin de Plancy, Stounik wiedzy tajemnej, wyb. i tł. M. Karpowicz, wst. P. Kuncewicz, Warszawa 1993, s. 113-114. Por. S. B. Linde, Stoumik jezyka polskiego, t. 2, Warszawa 1994, s. 21-22; 1. Krasicki, Zbiór potrzebniejszych wiadomości, t. 2, Warszawa 1979 (przedr. z wyd. Lwów 1781), s. 88.

${ }^{3}$ W jakich okolicznościach najczęściej zauważamy, że coś jest magiczne lub że coś jest magią? Według Anny Engelking wtedy, kiedy „nie dostrzegamy, nie rozumiemy, czy nie umiemy w ramach własnego światopoglądu wytłumaczyć związku między jakąś przyczyną (czyimś działaniem) a jej skutkiem" (A. Engelking, Klatwa. Rzecz o ludowej magii stowa, Wrocław 2000, s. 19-20). Por. M. Buchowski, Magia. Jej funkcje i struktura, Poznań 1986, s. 5. 
tornia magiczna jest bardzo pojemna, praktycznie każdy przedmiot codziennego użytku lub istota żywa, w zasadzie wszystko może być obdarzone cechami nadnaturalnymi i służyć do operacji magicznych i wróżb. Często magiczny rekwizyt stanowi dar bogów lub istot nadprzyrodzonych ${ }^{4}$, a jego skuteczność uzależniona jest od cech użytkownika.

W artykule wykorzystano następujące teksty: Kazimierza Władysława Wójcickiego Zwierciadto Twardowskiego. Dialog we trzech sprawach roku 1628 wyprawiony $(1840)^{5}$, komedię Franciszka Zabłockiego Samochwat albo Amant wilkotak (1782) oraz Pieśn ciarlatańskq na jarmarku Adama Naruszewicza (1770). Łączy je użycie magicznych rekwizytów, krytyka wynaturzeń charakterystycznych dla Polski stanisławowskiej oraz tendencja do unaocznienia prezentowanych wydarzeń. Amanta wilkotaka i Zwierciadto Twardowskiego zbliża ponadto zastosowanie przez autorów tego samego chwytu konstrukcyjnego (teatr $\mathrm{w}$ teatrze).

\section{Magiczne zwierciadło}

Lustro już od czasów starożytnych budzi ambiwalentne odczucia ${ }^{6}$. Wynalezienie zwierciadła przypisuje się Hefajstosowi, który panował nad ogniem i tworzył cuda techniki ${ }^{7}$. Wedle wierzeń ludowych było ono tworem szatana. Wróżenie z lustra, czyli katoptromancję znawcy nauk tajemnych umieszczają w obrębie magii demonicznej i ceremonialnej (inaczej obrządkowej), wymaga bowiem przywołania demona i zawarcia z nim paktu formalnego lub milczącego. Wróżbita uzyskuje niezwykłe moce za cenę duszy, gdyż zgodnie z potocznym odczuciem źródło wiedzy znajdować się może tylko w królestwie podziemnym ${ }^{8}$. Przekonanie o demonicznym charakterze katoptromancji przenika do literatury. W Rozdzieleniu XVIII Postepku prawa czartowskiego przeciw narodowi ludzkiemu (1570): O pokusach przeszkadzajacych ludziom dokonano przeglądu diablów pod względem kompetencji. Czarnoksiężnikom, którzy posługują się zwierciadłami kryształowymi do przyzywania diabła i szukania skarbów oraz kruszców pomaga Farel.

Tegoż też czarta czarnoksiężnicy w swoich wsiach wzywają - pisze anonimowy autor Postępu prawa czartowskiego - którzy mają zwierciadła kryształowe, mają też swoje egzorcyzmy, oni zowią konjuracyje, któremi go przyzywają do onego zwierciadła, aby się ukazał chlopięciu (jeszcze nie-

\footnotetext{
${ }^{4}$ Przykładem może być Źółta szlafmyca Franciszka Zabłockiego.

5 Tekst stanowi część składową prozatorskiego Dialogu. Gawędy z XVI wieku.

${ }^{6}$ Zob. Lustro, w: J. E. Cirlot, Stownik symboli, tt. I. Kania, Kraków 2006, s. 237. Por. Lustro, w: P. Kowalski, Kultura magiczna. Omen, przesad, znaczenie, Warszawa 2007, s. 287.

7 Zob. R. Bugaj, Nauki tajemne w Polsce..., op. cit., s. 100.

${ }^{8}$ Jedno $z$ imion Szatana - Pyton — oznacza jasnowidza, a hebrajski wyraz 'VB, jakim się go określa, ducha zstępującego światła, dar proroctwa i magii (zob. D. de Rougemont, Udział diabła, tł. A. Frybes, Warszawa 1992, s. 127).
} 
winnemu) w onym zwierciadle; tamże przez znaki ukaże skarby w ziemi, gdzie kruszce będą ołowne, srebrne, złote albo o co będzie pytał majster?.

Wykorzystywane w dywinacji zwierciadła stawały się magicznym narzędziem poznania, pokazywały przeszłość, teraźniejszość i przyszłość, służyły do poszukiwań ludzi i przedmiotów oraz wyjawiania tajemnic. Wszechwiedzę lustra tłumaczy się jego szerokim „doświadczeniem” oraz z właściwością odbijania oczu — „ma” oczy, więc jest widzące, wiedzące, mądre ${ }^{10}$. Badacze nauk tajemnych znaleźli logiczne wyjaśnienie opisywanych zjawisk. Wedle nich, zwierciadło wywołuje w umyśle wpatrującej się w nie osoby treść podświadomą oraz halucynacje optyczne i akustyczne uważane za zjawiska obiektywne, i odpowiednio do intencji patrzącego interpretowane jako objawienia i przepowiednie przyszłości ${ }^{11}$.

Na ziemiach polskich przekonanie, że zwierciadło patrzy, wchłania obrazy i je zachowuje, rozpowszechnia się w renesansie wraz z rosnącą popularnością katoptromancji. Magicznych luster używali między innymi: autor okultystycznego dzieła o wróżeniu z błyszczących powierzchni Jan Trithemius, Katarzyna Medycejska, Nostradamus oraz mag królowej Elżbiety John Dee.

Zwierciadło Twardowskiego to przedmiot stricte magiczny - z racji sposobu wykorzystania i przynależności. Jego magiczność wynika nie tylko z przypisywanych mu nadprzyrodzonych właściwości, ale i niezwykłych cech właściciela - lustro należy wszak do najsłynniejszego polskiego czarnoksiężnika ${ }^{12}$. Według legendy, rodzimy Faust posługiwał się dwoma lustrami. Jedno z nich miał rzekomo otrzymać od biskupa krakowskiego Franciszka Krasińskiego, który przywiózł je z Wittenbergi. Wykonane z białego metalu, nieduże $(56$ x 46,5 cm), dziś pęknięte i zmatowiałe, znajduje się zakrystii kościoła parafialnego w Węgrowie ${ }^{13}$. Nie wiemy, w jaki sposób czarnoksiężnik wykorzystywał swoje lustra i czy posłuży się nimi do wywołania ducha Barbary Radziwiłłówny. Potrzeba racjonalnego wytłumaczenia każe oświeconym sprowadzić czary Twardowskiego do poziomu naukowego eksperymentu.

\section{Twardowski - czytamy w Zbiorze potrzebniejszych wiadomości - w wieku XVI profesor Akademii Krakowskiej, tenże ucząc fizyki rozmaite fizyczne czynił doświadczenia, wzięty od pospolitego gminu za czarnoksiężnika, i stąd roz- maite w dalszym czasie rozsiane bajki w zakątach jeszcze mające trwałości ${ }^{14}$.}

\footnotetext{
${ }^{9}$ Postępek praúa czartouskiego przeciw narodowi ludzkiemu, wyd. A. Benis, Kraków 1891, s. 99.

${ }^{10}$ Zob. M. Wallis, Dzieje zuierciadła i jego rola w różnych dziedzinach kultury, Łódź 1956, s. 81-83.

11 Zob. R. Gansiniec, Krystalomancja, Wrocław 1955, s. 4.

${ }_{12}$ O Twardowskim zob. R. Bugaj, Nauki tajemne w dawnej Polsce - Mistrz Twardouski, Wrocław 1993.

13 Publikacje dotyczące węgrowskiego zwierciadła zestawia Roman Bugaj w książce: Nauki tajemne $w$ dawnej Polsce..., op. cit., s. 263. Zob. także R. Kaleta, Sensacje z dawnych lat, Wroclaw 1974, s. $454-455$.

${ }^{14}$ I. Krasicki, Zbiór potrzebniejszych wiadomości, op. cit., s. 557.
} 
W utworze Wójcickiego magiczne zwierciadło jest najważniejszym rekwizytem spektaklu. Dostarcza sposobności do zaprezentowania satyrycznych scenek malujących wady osiemnastowiecznej szlachty. Podobny motyw odnajdziemy w Kuglarzach Ignacego Krasickiego (Bajki nowe IV 16) ${ }^{15}$. Jeden z tytulowych iluzjonistów w ten sposób zachęca widzów do uczestnictwa w przedstawieniu:

Patrzcie, cuda ujrzźycie,

Oto zwierściadło,

Co wszystko zgadło ${ }^{16}$.

Akcja dialogu Wójcickiego toczy się około 1595 roku w jaskini na Podgórzu, nazywanej przez lud katedrą Twardowskiego, gdzie mistrz szkoli swego ucznia ${ }^{17}$. Czarnoksiężnik, ulegając prośbie Klechy, pokazuje mu „cuda sztuki”, inscenizując przedstawienie, które polega na wywołaniu w lustrze wizji ukazujących przyszłość. W tym celu ustawia naprzeciw siebie dwa zwierciadła $z$ polerowanego metalu, a między nimi ustawia zapaloną lampę ${ }^{18}$. Następnie czarnoksiężnik kreśli w powietrzu koło. Czynność ta sugeruje, że głównym animatorem przedstawienia jest diabeł - wielki iluzjonista. Zaznaczony laską krąg wyznacza obszar, w którym mag czuje się zabezpieczony przed atakiem czarta. O tym, że źródlem informacji są siły piekielne, świadczy również fakt, że czarnoksiężnik nie jest w stanie odsłonić własnej przyszłości:

Jako! chcesz mi ukazać obrazy przyszłości, a swojej mi nie ukażesz? ${ }^{19}-$

pyta swojego mistrza zdziwiony Klecha [s. 52]. Diabeł pokazuje wyłącznie to, co chce pokazać. Magia połączona zostaje tu z szatańską przewrotnością, a jej narzędzie uznane za instrument diabła służący do zwodzenia ludzi ${ }^{20}$.

Twardowski wywołuje kolejne obrazy na różne sposoby, co sugeruje, że w pełni kontroluje przebieg widowiska: „bije w dłon”, ,uderza laską lub nogą w podłoge”, „klasz-

${ }^{15}$ Utwór ten jest przeróbką bajki Johna Gaya Les jongleurs (I, 41), który wykorzystał wzorzec stworzony przez La Fontaine'a. Przed Krasickim thumaczył ją Jan Albertrandi (Z. Goliński, Komentarze, w: I. Krasicki, Pisma poetyckie, opr. Z. Goliński, t. 2, Warszawa 1976, s. 450-451).

${ }^{16}$ Ibidem, s. 187.

${ }^{17}$ Klecha wspomina o opublikowanym w tym właśnie roku Sejmie nieurieścim Marcina Bielskiego jako dziele świeżo wydanym (K. W. Wójcicki, Stare gawę́dy i obrazy, t. 2, Warszawa 1840, s. 49).

${ }^{18}$ Metalowe lustra należały wówczas do najpopularniejszych, dawały jednak niezbyt wyraźne odbicie. Zob. M. Wallis, Dzieje zwierciadła..., op. cit., s. 67.

${ }^{19}$ Wszystkie przytoczone cytaty pochodzą z wydania: K. W. Wójcicki, Stare gawędy i obrazy, op. cit., z paginacją w nawiasie.

${ }^{20}$ Magiczne właściwości lustra Twardowskiego są przedmiotem zainteresowania Ewy Szczepan w artykule Zwierciadto jako przedmiot magiczny w uybranych dramatach polskich pierwszej potowy XIX wieku, w: Lustro (zwierciadto) $w$ literaturze i kulturze, red. A. Borkowski, E. Borkowska, M. Burta, Siedlce 2006, s. 99-108. Autorka poddaje analizie również przywołany tu dialog. 
cze”, „rzuca garść maku”. Sekwencja obrazów obejmuje kilkanaście scenek. Oglądamy je nie bezpośrednio, lecz oczyma Klechy. Pierwszy obraz pokazuje warcholstwo polskiej szlachty, drugi — śmierć Sebastiana Klonowica, trzeci i czwarty — bezkrytyczne przyjmowanie cudzoziemskiej mody i brak poszanowania rodzimego stroju oraz języka. W magicznym zwierciadle dostrzeżemy również Józefa Szymanowskiego recytującego fragment Światyni Wenery $w$ Knidos i Tomasza Kajetana Węgierskiego, który pijany, z przekrzywionym żabotem śpiewa Ongi $z$ Jagusiq swoja $w$ gaiku. Zobaczymy także starostę kaniowskiego w chwili, gdy dokonuje zabójstwa wiejskiej dziewczyny, o czym śpiewały ludowe pieśni, oraz konfabulującego Karola Stanisława Radziwiłła „Panie Kochanku”. Autora nie interesuje charakterystyka wewnętrzna prezentowanych postaci, raczej za pomocą wyolbrzymienia zatrzymuje uwagę czytelnika na wybranym szczególe wyglądu zewnętrznego (puder, peruka jako symbol sfrancuzienia), charakterystycznej cesze bądź jakimś epizodzie z jej biografii. Wójcicki daje wyraz swej niechęci wobec nowego gustu, estetyki rokoka i naśladowania obcych wzorów obyczajowych (libertynizm).

Poziomy iluzji mnożą się — w zwierciadle czarnoksiężnika ujrzymy jedną ze scen Sarmatyzmu Franciszka Zabłockiego oraz fragment Marii Antoniego Malczewskiego. Wprowadzenie w ostatniej scenie Mikołaja Reja, przedstawiciela renesansu - okresu postrzeganego wówczas jako wiek autentycznych cnót — sugeruje, że krytyczna ocena rzeczywistości dokonywana jest z pozycji retrospektywnego ideału społecznego.

Następujące po sobie scenki to przykłady ilustrujące kolejne przejawy coraz głębszej demoralizacji społeczeństwa, a ich ocena - tendencyjna i jednostronna - pochodzi od osoby wystylizowanej na naiwnego prostaczka, który z niedowierzaniem komentuje pojawiające się wizje:

Do djaska! cóż ja baczę! Stoi przed kramem jakiś Memec, pod napisem Moda, owoż wszystko tam spieszy, co żyje. Mily Boże! Żupany i pasy sprzedają niemal za darmo żydom - a drogo kupują jakieś rupiecie. Głowy okryli peruką, a kusa, by błazny wystrojeni, wspaniale pawim suną po rynku krokiem. [...] A niewiasty $z$ wpół obnażoną piersią, ogonami zmiatają kurzawę i śmiecie z bruku, a na biodrach przywiązują poduszki. [s. 53]

Wypowiedzi Klechy są zarazem nośnikiem treści humorystycznej. Komizm generują między innymi infantylne pytania ucznia czarnoksiężnika, opacznie interpretującego percypowane obrazy (na przykład na widok upudrowanego fircyka reaguje: „Co to za młynarz, który tak umączony, a na pana wyziera?” [s. 54]). Powierzenie funkcji komentatora naiwnemu prostaczkowi, pozbawionemu krytycznego dystansu wobec tego, co widzi, wprowadza zarazem do dialogu ton niepokoju i prowokuje pytanie o skalę czartowskiej manipulacji ${ }^{21}$. Wyłaniająca się z sekwencji obrazów wizja

${ }^{21}$ Jej pierwowzory odnajdziemy $\mathrm{m}$. in. u Diderota i Woltera. 
przyszłości, uzupełniana konstatacjami Klechy o kondycji Polski następnych pokoleń, jest skrajnie pesymistyczna:

Jeżeli kiedy trąba Michała Archanioła wzbudzi zmarłych, w naszym plemieniu jednej pieśni Bogu w jednym nie zanucim języku —

prorokuje Klecha [s. 57-58]. Gdy Twardowski próbuje wywołać jakieś optymistyczne sceny (ufność w Bogu konającego poety, przebudzenie patriotyczne Polaków w „godzinie rozumu i odwagi"), percypowany obraz się zaciera. Zwierciadła calkowicie podlegają czartowskiej mocy, pokazują świat zniekształcony, przy czym deformacja nie wynika ani z praw optyki - lustro zawsze pokazuje widoki odwrócone - ani z ich budowy ${ }^{22}$, ale $\mathrm{z}$ diabelskiej genezy prezentowanych wizji. To czart zaciemnia obraz rzeczywistości, przedstawiając jej karykaturę.

\section{Wilkołak}

Wilkołak należy do stworzeń półdemonicznych, łączonych z działalnością czarownic. Uchodzi za najbardziej mściwe spośród nich, budząc lęk wśród wiejskiej społeczności jeszcze w XIX wieku ${ }^{23}$. Różni się od innych członków stada wyglądem i zachowaniem, posiada więc cechy wilka, lecz przerażająco wyolbrzymione. Większy niż inne wilki, ma nienaturalnie duży pysk, niekiedy dwie pary oczu i ludzki głos ${ }^{24}$. Postać wilkołaka pojawiała się częściej w twórczości ludowej niż wysokiej, gdzie zazwyczaj była nośnikiem idei podwójnej natury człowieka oraz symbolem jego podwójnej kondycji: rozumnej i zwierzęcej ${ }^{25}$. W Samochwale Franciszka Zabłockiego (przeróbce francuskiej adaptacji Wesołych kumoszek z Windsoru pochodzącej z 1782 roku) wilkołak od początku jest postacią symboliczną. Zabłocki wprowadza go do komedii, aby zdemaskować i skompromitować tytułowego bohatera - zarozumiałego fircyka i mitomana, Pana Chwaliburcę. Wiara w wilkołaki funkcjonuje w sztuce autora Fircyka $w$ zalotach już tylko jako przesąd kultywowany przez zabobonników na odległej prowincji:

powiedział, ze zabił wilkołaka, święta prostota uwierzyła temu. [...] Jakże ci parafianie są łatwowierni ${ }^{26}$ [s. 447].

22 Krzywe zwierciadła, o powierzchniach krzywych, wklęsłych lub wypukłych, kulistych, parabolicznych lub walcowatych znane były od starożytności. Zniekształcały one rysy przeglądających się w nich postaci, dając ich karykaturę. Zob. M. Wallis, Dzieje zwierciadła..., op. cit., s. 69-70.

${ }_{23}$ Zob. L. Pełka, Polska demonologia ludowa, Warszawa 1987, s. 202-203.

${ }^{24}$ Zob. B. Baranowski, W kregu upiorów i wilkołaków, Łódź 1981, s. 154.

${ }^{25}$ Por. L. P. Słupecki, Wojownicy i wilkołaki, Warszawa 1994, s. 185-201 (rozdz. 9: Wilkołactuo jako motyw literacki).

${ }^{26}$ Wszystkie przytoczenia pochodzą z edycji: Teatr Franciszka Zabłockiego, opr. J. Pawłowiczowa, t. 1: Pogranicze farsy i komedii obyczajowej, Wrocław 1994. 
Zabobonnik miał wiele mutacji i bynajmniej nie występował tylko na sarmackiej wsi (akcja sztuki toczy się na pograniczu Śląska).

Zabłocki proponuje widzom zabawę $\mathrm{z}$ wilkołakiem, która przybiera formę próby, jakiej z inicjatywy uwodzonych kobiet poddany będzie Chwaliburca. Ujawni ona prawdziwą naturę mężczyzny i wyleczy z zazdrości męża jednej z bohaterek („Zawiść i fanfaronada są dwie choroby, które dzisiaj uleczyć muszę" [s. 469]). Ten antenat Fredrowskiego Papkina jest zarazem śmieszny i groźny. Podszyty strachem „zabójca smoków i wilkołaków" rozpowiada naokoło o swoich miłosnych podbojach. Damy nie biorą jego zalotów na poważnie, ale zdają sobie sprawę z niebezpieczeństwa kompromitacji, bowiem mąż jednej z nich ma wątpliwości co do uczciwości swojej żony.

Sprytne kobiety zawiązują intrygę, której celem jest zdemaskowanie i ośmieszenie niewydarzonego amanta. Oszustwo jest tu katalizatorem dobrej sprawy. Namówiony przez adorowane damy, Chwaliburca godzi się na udawanie wilkołaka w celu nastraszenie męża jednej z nich. Tymczasem to on staje się ofiarą maskarady, w której nie do końca świadomie bierze udzia2 ${ }^{27}$. Opis wilkołaka w „całym rynsztunku nastraszenia”, umieszczony w didaskaliach, prezentuje go jako postać komiczną, pozbawioną wszelkiej grozy:

sierść udaje kożuch włosem wywrócony do góry, czapka takoż kosmata z rogami jelenia, maska w ręku brzydka, ale nie nadto straszna, może być jakiegoś zwierzęcia [s. 507].

W takich kostiumach występowali zapewne grasujący po wsiach oszuści, a potem kolędnicy. Pokazuje to jednocześnie, jak bardzo w XVIII wieku wyobrażenie tej postaci było już skonwencjonalizowane i odrealnione. W sztuce Zabłockiego traktowana jest ona z przymrużeniem oka, co wplywa na daleko posuniętą umowność kreacji. Mamy do czynienia $z$ hybrydą, wyposażoną w rogi, których wilk jest przecież pozbawiony. Atrybut zdradzonych mężów stanowi aluzję do działalności Chwaliburcy:

wkrótce z mojej głowy macie przenieść się na łeb jego [s. 510] —

ale, jak się okazuje,

najstraszniejszym dla zalotnika wilkołakiem jest mąż niespodzianie z drogi przybywający [s. 450].

Prędzej go znajdziemy w mieście, Gdzie łatwo sztuki niewieście

Z czleka zrobią wilkołaka -

stwierdza bywały w świecie Zawierucha [s. 520].

${ }^{27}$ Maskarada należy do wyjątkowo nośnych sposobów generowania komizmu. 
Kobiety starannie przygotowują przedstawienie. Bierze w nim udział ponad dwadzieścia osób. Reżyserem, scenarzystą oraz odtwórczynią jednej z głównych ról (,ja z Szymonową wymyśliłam bajkę o przebywaniu we wsi naszej wilkołaka” [s. 500]) jest Pani Oberżer (która gra Prozerpinę). W czwartym i zarazem ostatnim akcie akcja komedii przenosi się na Łysą Górę, miejsce sabatów czarownic, gdzie z okazji dnia wilkołaków zbierają się wszelkie stworzenia demoniczne i półdemoniczne. Wśród zgromadzonych zauważamy zwierzęta demoniczne (puchacze, pawie, sowy, nietoperze), diabły (Asmodeusza, Borutę, Smołkę, Latawica, Lelka, Lewiatana, Belzebuba), upiory, czarownice i Bobo - „małego dziwotworka, który towarzyszy czarownicom na sabatach" i pełni funkcję wyroczni (wedle zaleceń zawartych w didaskaliach, „można mu dać ksztalt capa, kota, pysk rozwarty, dwie małe latarki otwarte w oczach” [s. 518]).

$\mathrm{Na}$ Łysej Górze obecna jest również Prozerpina, uosabiająca siły przyrody i pełniąca funkcję przełożonej podziemnych mocy. Demony wyczuwają obecność Chwaliburcy, chwytają go i wymyślają dlań okrutną karę za zabicie wilkołaka — smołę, rożen i stos. To represje, jakim zwykle poddawane są czarownice i heretycy („nie jestem ani apostata, ani czarownik, za cóż mię tym rodzajem śmierci karać?” - pyta przestraszony Chwaliburca [s. 516]). Jesteśmy świadkami sparodiowanego procesu o czary, procesu „na wspak”.

Przerażony Chwaliburca przyznaje się, że nigdy nie zabił wilkołaka, a nawet dotąd nie widział żadnego na oczy. Przy okazji wychodzi też na jaw, że nigdy nie uwiódł żadnej kobiety. Postać wilkołaka pełni w sztuce funkcję lustracyjną. Jest straszakiem i weryfikatorem postaw bohaterów. Demaskuje zabobonników, obnażając ich głupotę i łatwowierność:

Wilkołak dzieci nabawia trwogi,

Wiele i starych bab, że jest, mniema,

Ma on być ślepy, mieć wielkie rogi,

Ja to wiem tylko, że głowy nie ma.

Szukać go w lasach wiara prostaka [s. 520].

Wyolbrzymienie w karykaturze polega na przerysowaniu wizerunku, ośmieszającym charakterystyczne właściwości przedmiotu kpiny. W Amancie cechą tą jest tchórzostwo. Ujawnia się ono zarówno w charakterystyce bezpośredniej Chwaliburcy, dokonanej przez Zawieruchę — „krzywe odbicie” wiernego sługi (jego wypowiedzi mają wyraźnie prześmiewczy charakter), jak i w charakterystyce pośredniej tej postaci.

Przebieranki i aranżowanie teatru w teatrze to bardzo ważna cecha Samochwata. Maska i teatralna inscenizacja pełnią funkcję nie tylko estetyczną jako element intrygi, ale także są sposobem naprawiania świata. Przebieranki stwarzają doskonałą możliwość satyrycznego ataku. Kryje się w nich implicite wizja świata na opak, gdyż w urojonym świecie masek wszystko jest możliwe i wszystko okazuje się czym innym niz w rze- 
czywistości. Wszyscy — oprócz ofiary — bawią się doskonale. Janina Pawłowiczowa w tajemnych rytuałach dopatruje się elementów masońskich ${ }^{28}$. Rytual masońskiej loży adopcyjnej Zakonu Mopsów zdaniem Leviego miał być powtórzeniem ceremonialnego sabatu, przebiegał wśród tańców i biesiad, a przyszła „mopsica” całowała w zad mopsa lub wyobrażającą go figurkę; damy były jednak ubrane, nie wieszały u paska żywych kotów, nie spożywały mięsa noworodków - byl więc sabatem cywilizowanym ${ }^{29}$.

Skąd Zabłocki zaczerpnął pomysł dnia wilkołaków? O zgromadzeniach wilkołaków na podobieństwo sabatów wspomina w roku 1603 Boguet, a protestancki lekarz Casper Peucer w dziele Commentarius de Praecipibus Divinationum Generibus (1560) przytacza popularną w krajach baltyckich, a pochodzącą z Litwy opowieść o nocnym pochodzie wilkołaków prowadzonych przez diabła ${ }^{30}$.

$\mathrm{Na}$ „sabacie” diabły zdają Prozerpinie relację z ostatniego tygodnia — podają liczbę bankructw, skłóconych małżeństw, kradzieży, oszustw, przypadków fałszowania pieniędzy oraz innych intryg, będących ich udziałem. Zgromadzenie na Łysej Górze przypomina naradę sił piekielnych z Postepku prawa czartowskiego przeciw narodowi ludzkiemu. Motyw „sejmu piekielnego" pełni tam funkcję ramy pozwalającej autorowi na ustosunkowanie się do niekorzystnych zjawisk społecznych. W obu tekstach „sprawozdanie z diabelskiej działalności" staje się okazją do zaprezentowania typów satyrycznych i uosabianych przez nie ludzkich wad. Otrzymujemy przegląd charakterystycznych dla ówczesnej rzeczywistości schorzeń i wynaturzeń wraz z diagnozą, która brzmi: „pieniądz rządzi światem".

\section{Latarnia magiczna}

Problem kompromitowania i demaskowania fałszywych pozorów pojawia się również w Pieśni ciarlatańskiej na jarmarku ${ }^{31}$. Rolę magicznego rekwizytu gra tu „maluśka skrzyneczka”, w której można zobaczyć różne cuda. Przedmioty takie przynależą w oświeceniu do tzw. magii sztucznej, polegającej na łudzeniu oczu iluzjami, automatami lub umiejętnym wykorzystywaniu praw fizyki ${ }^{32}$. O tym, że cuda będą przedstawiane, dowiadujemy się w pierwszej zwrotce utworu:

W tej maluśkiej skrzyneczce, co ma świat obszerny

najciekawszego, zawarł rzemieślnik misterny.

${ }^{28}$ Zob. J. Pawłowiczowa, Komentarz, w: Teatr Franciszka Zabłockiego, op. cit, s. 588.

29 Zob. E. Levi, Historia magii, tł. J. Prokopiuk, Warszawa 2000, s. 323. Por. T. Cegielski, Sekrety masonów. Pienwszy stopień wtajemniczenia, Warszawa 1992, s. 113-117.

${ }^{30}$ Zob. R. H. Robbins, Encyklopedia czarów i demonologii, th. M. Urbański, Warszawa 1998, s. 316.

31 Zob. mój artykuł O „Pieśni ciarlatańskiej na jarmarku” Adama Naruszewicza, w: Adam Naruszewicz. Interpretacje, red. T. Chachulski, Wroclaw 2000, s. 37-55.

32 Zob. J. Collin de Plancy, Stownik wiedzy tajemnej, op. cit. 
Tu wszystkie rzeczy nowe, a kto spojrzy na nie, z podziwieniem zawoła: „Cuda, mości panie!”33

Tytuł Pieśn ciarlatańska na jarmarku oraz pojawiające się w tekście realia informują, że uczestniczymy w jarmarcznym przedstawieniu latarni magicznej, zwanej inaczej „szajnekatarynką" ${ }^{\text {"3 }}$ lub spektaklu tzw. teatru metamorfoz ${ }^{35}$. Prezentując przede wszystkim różne osobliwości i cuda, dawały one okazję do błahej rozrywki, w której upodobanie znajdowali przedstawiciele wszystkich warstw społecznych.

Publiczny seans latarni magicznej, zwany też inaczej latarnią czarnoksięską, polegał na wyświetlaniu przeźroczy do ułożonego tekstu. Publiczność poznawała kolejne epizody jakiejś ciekawej historii, oglądając na ścianie obrazy objaśniane przez narratora i mechanika w jednej osobie. Role bohaterów następujących po sobie scenek odgrywały dwuwymiarowe lalki poruszane przez animatora za ekranem. Nie przemawiały one same. Wydaje się, że latarnia dysponowała kilku systemami projekcji w zależności od tego, czy wyprowadzała obraz na zewnątrz, czy też nie. W Pieśni... widzowie podchodzą i pojedynczo zaglądają do pudha ${ }^{36}$. Świadczą o tym formy czasowników: „przystąp”, „widzisz”. W tej wersji miniaturowy rzeczywiście teatrzyk jarmarczny był teatrem jednego widza ${ }^{37}$. Teatr lalek nie byl realistyczny — pisal Mieczysław Klimowicz — ale dawał widzowi wrażenie iluzji, a jego magiczne działanie wynikało $\mathrm{z}$ abstrakcyjności aktorów, umowności, literackiej stylizacji i teatralnej symboliki widowiska, co pozwalało nieraz nasycić tekst czystą poezją, ciętą satyrą lub głęboką refleksją filozoficzną ${ }^{38}$.

Pieśn ciarlatańska na jarmarku przyjmuje kształt rewii typów ${ }^{39}$. Kolejno ukazywane postacie ilustrują incipitową tezę o niezwykłym charakterze widowiska. Funkcję

${ }^{33}$ Wszystkie przytoczenia pochodzą z edycji: A. S. Naruszewicz, Poezje zebrane, wyd. B. Wolska, Warszawa 2005 , t. 1 , s. $155-159$.

${ }^{34}$ Z szajnekatarynką wiąże konkretną osnowę tematyczną Pieśni... Jerzy Jackl (zob. Teatr Narodouy 1769-1794, pod red J. Kotta, Warszawa 1967, s. 358). Nazwa przedstawienia „szajnekatarynka” pochodzi od lalki, którą zwano „szermante” lub „szejne katarynka”. Tańczyła ona po podłodze do muzyki z katarynki towarzyszącej przedstawieniom. Jak pisze Antoni Magier, sprowadzili ją do Polski Włosi około 1760 r. (zob. Teatr Narodouy 1769-1794, op. cit., s. 358). Ciarlatan nosił „czarodziejskie pudło” na plecach, nie mogło być więc zbyt duże i ciężkie (zob. Z. Raszewski, Weryfikacja czarodzieja, „Polska Sztuka Ludowa" 1987, nr 1-4, s. 109-110).

35 „Maluśka skrzyneczka” mogła stanowić wczesne, rokokowe stadium teatru odmian, zredukowanego potem do czysto mechanicznej wirtuozerii. Zob. R. Wierzbowski, O szopce. Studia $i$ szkice, opr. M. Waszkiel, Łódź 1990, s. 16, 84.

${ }^{36}$ Seans latarni magicznej pokazują rysunki Norblina Latarnia czarnoksięska i Szejnekatarynka z 1787 r. Na drugim widzimy dzieci, które zaglądają do środka skrzyni, być może z ciekawości. Na rysunek ten zwrócił uwagę Ryszard Wierzbowski w Nocie do artykułu Co przedstawia obraz Jana Piotra Norblina "Les marionettes polonaises” („Pamiętnik Teatralny”, 1968, z. 2, s. 241-242).

${ }^{37}$ Zob. R. Wierzbowski, op. cit., s.15.

${ }^{38}$ Zob. M. Klimowicz,. Początki teatru stanisfawowskiego (1763-1773), Warszawa 1965, s. 384.

${ }^{39}$ Lalki mają naturalne predyspozycje do prezentacji typów. 
łączników między nimi pełnią wyrażenia typu: „Ten zaś...”; „...oto pan”; „A toż...”; „I to...”. Naruszewicz jako cuda prezentuje ludzi idealnych, których zalety pozostają w jawnej sprzeczności z ich ujemną w powszechnej opinii reputacją. Oglądamy je w sytuacjach kłócących się z powszechnym wyobrażeniem. Satyry rozpowszechniły stereotypowe ujęcia fircyków, dam modnych, dworaków czy filutów. Bohaterowie Naruszewicza od tych stereotypów odbiegają wyraźnie. Są to jak gdyby „antystereotypy", będące zaprzeczeniem funkcjonujących powszechnie wyobrażeń społecznych o charakterystycznych cechach członków różnych zbiorowisk ludzkich, określonych środowisk, warstw czy zawodów. Blizej im do pozytywnych wzorców osobowych podporządkowanych idealnej koncepcji moralności obywatelskiej. W kolejnych odsłonach dramatycznych oglądamy bowiem: pana, który choć bogaty i strojny, nie jest hardy; dworzanina, który „nie zna, co pochlebstwo, co zazdrość przeklęta”; dwór nieprzesiąknięty atmosferą panegiryzmu, fałszu i zakłamania; niezadłużonego magnata w otoczeniu wiernych sług, które go nie okradają; bogacza, który nie ciśnie biednego i pamięta o swoim pochodzeniu; skromnego mędrca; hazardzistę z pieniędzmi; wiernego przyjaciela; zgodne małżeństwo; dobrze wychowane dzieci; mędrka, który jest „przy rozumie”; uczciwego adwokata, co „nie szarpie sławy”; odważnego junaka; nieprzekupnego sędziego; wreszcie cnotliwą damę i młodzieńca cieszącego się dobrą opinią.

Uczestnikami rewii są również:

polityk, a nie szalbierz, bogacz, a nie zdzierca, wdzięczny za dobrodziejstwa, żołnierz nie bluźnierca, szczęśliwy tak, że go nic w życiu nie zasmuci, poczciwy tak, że mu nic żaden nie wyrzuci ${ }^{40}$.

W sumie poznajemy kilkanaście postaci. Podmiot mówiący rezygnuje z ich dokładniejszego portretowania, ponieważ wprowadzając na scenę kilkanaście równorzędnie potraktowanych osób, nie może skupić się wyłącznie na jednej. Bohaterowie prezentowani są w różnorodny sposób. Pierwsza postać ukazana jest w „naturalnej scenerii” — we własnym domu:

Oto pan siedzi w złotogłowie strojny $[\ldots]$

Obok przy nim dworzanin.

Następną zaprezentowano w podobny sposób, znów pojawia się wielmoża w otoczeniu swoich sług. Obie figury są dość dokładnie opisane - poeta zwraca szczególną uwagę na ich wygląd zewnętrzny. Zwykle u Naruszewicza demaskuje on cechy

${ }^{40}$ Julian Platt zwraca uwagę, że czterech ostatnich postaci nie ma we francuskim pierwowzorze. Zob. idem, Zabawy Przyjemne i Pożyteczne 1770-1777. Zarys monografii pieruszego polskiego czasopisma literackiego, Gdańsk 1986, s. 59. 
ośmieszane i deprecjonujące, tu ubiór bohaterów (złotogłów strojny, sobole zwisające od kołnierza) przede wszystkim symbolizuje ich pozycję społeczną i materialną. Pozostałe osoby zostały zaledwie wymienione (polityk, żołnierz niebluźnierca).

Naruszewicz za pomocą zwrotów: „widziałżeś...”; „widzisz...” nieustannie podkreśla, że jego bohaterowie dostępni są bezpośredniej obserwacji, przez co ujawnia się nowa wówczas w utworach satyrycznych tendencja do tworzenia iluzji naoczności przedstawionego czytelnikowi obrazu ${ }^{41}$. Dogodne warunki do opisu i bezpośredniej oceny przedstawionych postaci poeta uzyskał dzięki powiązaniu konstrukcji Pieśni... ze strukturą teatru lalek, głównie przez wprowadzenie narratora - tytułowego ciarlatana urządzającego dla dość różnorodnej publiczności platne widowiska. Słowo „ciarlatan” w XVIII w. funkcjonowało w dwóch znaczeniach. Pierwsze początkowo oznaczało fałszywego lekarza, który „bez nauki lekarskiej wtrąca się w praktykę jej, łudząc łatwowiernych okazałością mniemanych sekretów", a z czasem kuglarza i magika ${ }^{42}$. Pokazywanie „cudów” to jego sposób zarabiania na życie. We wszystkich słownikach eksponuje się oszustwo, moment udawania, gry jako podstawę fachu ciarlatanów Akcja przedstawiona na miniaturowej scenie jest właściwie ilustracją dla tekstu narratora. Mali aktorzy nie grają $z$ wlasnego popędu, ale służą jako maski teatralne twórcy spektaklu. Można to zaobserwować w dawnych prymitywnych przedstawieniach, w których opowiadaniu kuglarza, wyposażonego w czarodziejską laseczkę towarzyszyły odpowiednie ruchy i gesty lalek ${ }^{43}$. Pieśń... ukazuje świat współczesny widziany oczyma „człowieka z dołu”. Co najmniej kilka razy pozwala sobie na powątpiewanie w istnienie ludzi, którzy odbiegaliby od zasady powszechnego zepsucia: „prawdziwie, ja sam na te dziwy krzyknąć muszę”; „A toż pewnie nie dziwna...”; „Jest się czemu zadziwić...”; „i to się rzadko nader trafia w ludzkim rodzie". Poczynione w kolejnych zwrotkach zestawienia podmiot autorski dyskwalifikuje ostatecznie za pomocą refrenu, który stale przypomina, że ukazany świat jest tylko iluzją uzyskaną przy pomocy magicznego pudełka. Sugeruje to również końcowy fragment Pieśni... z ,gombrowiczowskim” zakończeniem:

Pieśń moja tak ucieszna, tak skromna, tak miła, by ganiąc obyczaje, osób nie ganiła, gdy ją każdy pochwali ani okiem krzywym rzuciwszy na nią, rzeknie tonem obraźliwym: „Kto pisał, wielki musiał być duda”.

\footnotetext{
${ }^{41}$ Zob. M. Grzędzielska, T. Kostkiewiczowa, hasło Satyra, w: Stounik literatury polskiego ośuiecenia, red.

T. Kostkiewiczowa, Wrocław 1991, s. 560.

${ }^{42}$ Zob. S. B. Linde, Stounik jezyka polskiego, t. 1, Lwów 1854, s. 289; Por. J. Karłowicz, A. Kryński, W. Niedźwiedzki, Słownik jezyka polskiego, Warszawa 1900, s. 317; M. Arct, Słownik ilustrowany jęzka polskiego, t. 2, Warszawa 1929, s. 869.

${ }^{43}$ Zob. M. Klimowicz, Początki teatru stanisławowskiego, op. cit.
} 


\section{Zakończenie}

We wszystkich omawianych utworach magiczny rekwizyt odsłania prawdziwą naturę człowieka i pokazuje nagą prawdę o otaczającym go świecie. Użycie rekwizytu umotywowane jest formalnie i stanowi oryginalną próbę udoskonalenia tradycyjnych technik satyrycznych, ukierunkowaną na uzyskanie iluzji naoczności. Żaden z przywołanych wyżej tekstów nie jest typową satyrą, wszystkie zawierają jednak elementy charakterystyczne dla tego gatunku literackiego. Autorzy przyjmują w nich krytyczną postawę wobec przedstawionej rzeczywistości, nie aprobują współczesnej moralności, upadku obyczajów i starych autorytetów. Krytyce i negacji towarzyszy tendencja dydaktyczna. W tekstach odnajdziemy znane z kart literatury stanisławowskiej typy satyryczne - podróżującego po Europie utracjusza, modną damę, chudego literata, zabobonnika, lichwiarza czy nieuczciwego jurystę. Autorzy Pieśni ciarlatańskiej na jarmarku i Zwierciadła Twardowskiego dają całą ich galerię, Zabłocki zaś skupia się na jednej ośmieszanej postaci. 